\title{
The Effects of Nalidixic Acid on Respiratory Activity of Asynchronous and Synchronous Cultures of Alcaligenes eutrophus
}

\author{
By C. EDWARDS* AND R. J. MCCANN \\ Department of Microbiology, Life Sciences Building, University of Liverpool, P.O. Box 147, \\ Liverpool L69 3BX, U.K.
}

(Received 25 June 1982)

\begin{abstract}
Nalidixic acid inhibited DNA synthesis and cell division during asynchronous growth of Alcaligenes eutrophus but treated cells continued to grow as monitored by $A_{550}$, respiratory activity and cell volume. Differential effects on cell division were seen when the antibiotic was added at different times during synchronous growth. The earlier in the cell cycle the time of addition the greater the inhibition of cell division. These results suggests that chromosome replication is confined to the first half of the cell cycle in $A$. eutrophus grown at $30^{\circ} \mathrm{C}$. Respiration rates of cells selected by continuous-flow centrifugation and immediately treated with nalidixic acid increased in a stepwise fashion. These steps were similar to those observed in untreated control cells and imply that the DNA-division cycle is not the causal factor for the periodicities in respiration rates and ATPase activity that have been previously reported in this bacterium.
\end{abstract}

\section{INTRODUCTION}

Periodic changes in respiratory activity have been reported in synchronous cultures of Escherichia coli (Evans, 1975; Poole, 1977), Alcaligenes eutrophus (Edwards \& Jones, 1977) and Bacillus subtilis (Edwards \& McCann, 1981). These changes are thought to reflect a changing demand for energy during the cell cycle, and in $A$. eutrophus and $E$. coli have been shown to correlate with periodic rises in ATPase activity (Edwards et al., 1978; Scott et al., 1980). A number of cellular processes could exert a changing energy requirement during the cell cycle. Prime candidates are those events which occur at specific times during the cell cycle. In bacteria, these include events concerned with chromosome replication and cell division, which occur at temporally fixed phases of the cell cycle, providing that the cycle time is sufficient for the completion of a C and D period (James, 1978).

We have investigated respiratory activity in asynchronous and synchronous cultures of $A$. eutrophus in which both chromosome replication and cell division have been inhibited by nalidixic acid. The cells continued to grow as filaments at rates similar to those observed in untreated control cultures. Periodic rises in respiratory activity persisted in cells selected on the basis of size by continuous-flow centrifugation and treated with nalidixic acid. These results imply that in $\boldsymbol{A}$. eutrophus periodic rises in oxygen uptake rates are not coupled to the DNAdivision cycle.

\section{METHODS}

Maintenance and growth of the organism. Alcaligenes eutrophus H16, ATCC 17699 was maintained on plates of nutrient agar. Growth in liquid salts medium, preparation of synchronous cultures by continuous-flow centrifugation and assessment of synchrony were as described previously (Edwards \& Jones, 1977).

Analytical methods. Growth was followed by measuring the $A_{550}$ of the culture or by determining cell numbers using a Coulter counter model ZBI fitted with a $30 \mu \mathrm{m}$ orifice (Coulter Electronics, Harpenden, Herts.) in culture samples which had been appropriately diluted in the electrolyte solution Isoton II (also supplied by Coulter 
Electronics). All counts were corrected for coincidental passage. Modal cell volumes were measured using a Channelyzer C-1000 linked to an X-Y plotter. Calibration of the channelyzer readout was done by using latex particles of $1 \cdot 15 \mu \mathrm{m}$ diameter.

Oxygen uptake was measured polarographically at $30^{\circ} \mathrm{C}$ using a Rank oxygen electrode (Rank Bros, Bottisham, Cambs.) linked to a Vitatron chart recorder (MSE, Crawley, Sussex). Samples $(2.4 \mathrm{ml})$ of undiluted cell suspensions were rapidly transferred from growing cultures into the reaction chamber and oxygen uptake rates followed for approximately $5 \mathrm{~min}$.

Total DNA content in culture samples was determined by the diphenylamine method of Burton (1956).

Chemicals. Stock solutions $\left(2 \mathrm{mg} \mathrm{ml}^{-1}\right)$ of nalidixic acid (Sigma) were made up in $70 \mathrm{~mm}-\mathrm{NaOH}$. Appropriate additions of $70 \mathrm{~mm}-\mathrm{NaOH}$ were made to control cultures and no effects on growth or modal cell volume were observed.

\section{RESULTS}

\section{Effects of nalidixic acid during asynchronous growth}

During asynchronous growth, control cultures of $A$. eutrophus grew with a doubling time of $75 \mathrm{~min}$ as determined by increase in cell numbers and $A_{550}$. Oxygen uptake rates $\left[\mathrm{nmol} \mathrm{O}_{2}\right.$ consumed $\min ^{-1}(\mathrm{ml} \text { culture })^{-1}$ ] and the amount of DNA ( $\mu \mathrm{g}$ per $20 \mathrm{ml}$ culture) also increased at similar rates. Modal cell volume remained relatively constant at approximately $0.8 \mu \mathrm{m}^{3}$ throughout the growth period (Fig. $1 a$ ). When nalidixic acid [10 $\left.\mu \mathrm{g}(\mathrm{ml} \text { culture) })^{-1}\right]$ was added to exponentially growing cells (time 0 ), $A_{550}$ and oxygen uptake rates continued to rise at rates similar to those in the control culture. Both cell division and amounts of DNA also continued to rise for approximately $55 \mathrm{~min}$ but thereafter stopped and remained constant. Modal cell volume remained at approximately $0.8 \mu \mathrm{m}^{3}$ for the first $55 \mathrm{~min}$ after the addition of nalidixic acid but thereafter began to rise such that at 120 min the modal cell volume of the culture was $1.3 \mu \mathrm{m}^{3}$. This result indicates that although DNA synthesis and cell division are inhibited by nalidixic acid the treated cells continue to grow at rates similar to control cells. Microscopic examination of nalidixic acid treated cultures showed the presence of longer filamentous cells. The distribution of cell volumes $180 \mathrm{~min}$ after addition of nalidixic acid is compared with that of untreated cells in Fig. 2. Control cell volumes ranged between 0.5 and $2 \mu \mathrm{m}^{3}$ (modal volume approximately $0.9 \mu \mathrm{m}^{3}$ ). The nalidixic acid treated culture contained a much broader distribution of cell volumes, between approximately 0.7 and $4.5 \mu \mathrm{m}^{3}$ (modal cell volume approximately $2 \cdot 2 \mu \mathrm{m}^{3}$ ). These results confirmed the continued growth of cells after antibiotic treatment.

\section{Effects of nalidixic acid during synchronous growth}

The effects of nalidixic acid at different stages of synchronous growth were determined. Cell cycle specific effects were apparent. After selection by the continuous-flow centrifugation method, untreated control cells of $A$. eutrophus divided synchronously after 50 min incubation. Cell numbers increased from $1.5 \times 10^{7}$ to $3 \times 10^{7}$ bacteria $\mathrm{ml}^{-1}$. A second synchronous division occurred at approximately $125 \mathrm{~min}$. The duration of the cell cycle was $75 \mathrm{~min}$, similar to the generation time of exponentially-growing cells. Culture density, as determined by $A_{550}$, increased exponentially with a doubling time of $75 \mathrm{~min}$. Addition of nalidixic acid at time 0,20 or $60 \mathrm{~min}$ after selection resulted in an increasing percentage of cells dividing (approximately 18, 48 and $72 \%$, respectively, compared with the untreated control). However, there was no second division in the nalidixic acid treated cells, although the $A_{550}$ of all the treated cultures rose in similar fashion to the control cells (Fig. 3). Therefore nalidixic acid inhibited cell division to a greater extent when added in the early stages of the cell cycle.

\section{Measurements of oxygen uptake in cells selected by continuous-flow centrifugation and treated with nalidixic acid}

The addition of nalidixic acid to cells immediately after selection by continuous-flow centrifugation almost totally inhibited synchronous division (Fig. 3). It was therefore possible to investigate, in the absence of chromosome replication and cell division, the periodic rises in respiration rates previously reported in A. eutrophus (Edwards \& Jones, 1977). Addition of the 

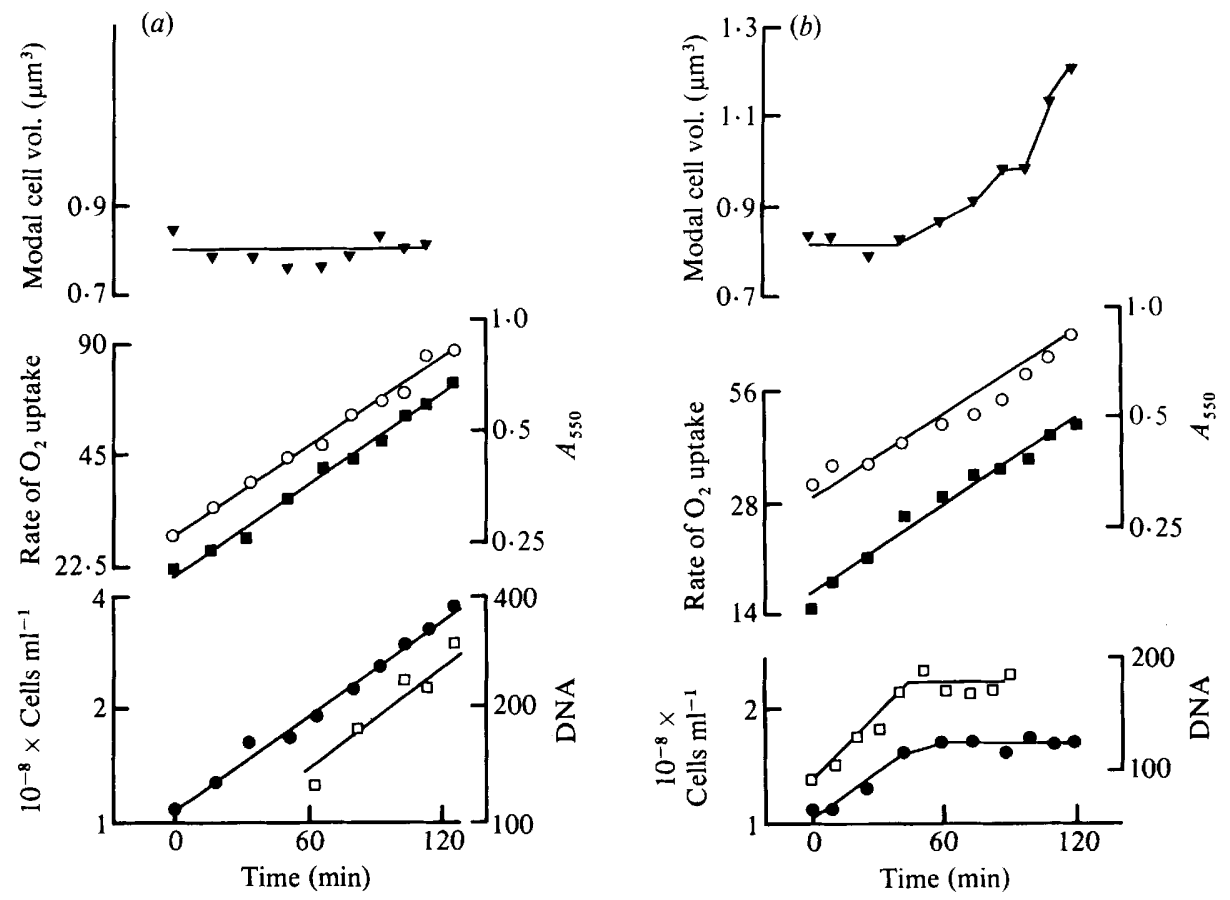

Fig. 1. Effects of nalidixic acid $\left(10 \mu \mathrm{g} \mathrm{ml}^{-1}\right)$ on asynchronous cultures of Alcaligenes eutrophus. (a) Untreated exponentially-growing culture; (b) nalidixic acid-treated exponentially-growing

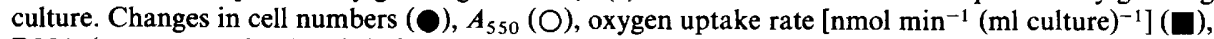
DNA ( $\mu$ g per $20 \mathrm{ml}$ culture) $(\square)$ and modal cell volume $\left(\mu \mathrm{m}^{3}\right)(\nabla)$ are shown.

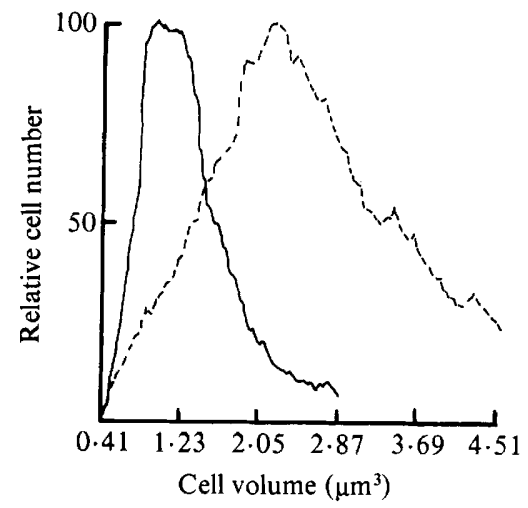

Fig. 2. Distribution of cell volumes in cells of $A$. eutrophus grown asynchronously in the absence ( - ) or presence $(-\cdots)$ of nalidixic acid $\left(10 \mu \mathrm{g} \mathrm{ml}^{-1}\right)$.

antibiotic to selected cells immediately after continuous-flow centrifugation resulted in continued increase in $A_{550}$ at rates similar to control cells. Approximately $20 \%$ of the cells divided after $50 \mathrm{~min}$, thereafter cell numbers remained constant. Oxygen uptake rates rose discontinuously as a series of steps of similar periodicity to those seen in synchronously-growing cells (Fig. 4). 


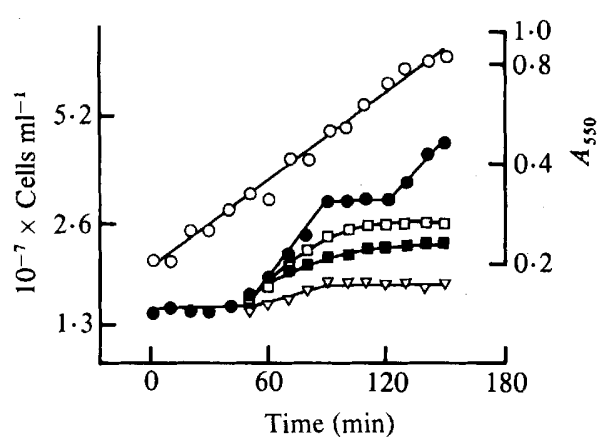

Fig. 3
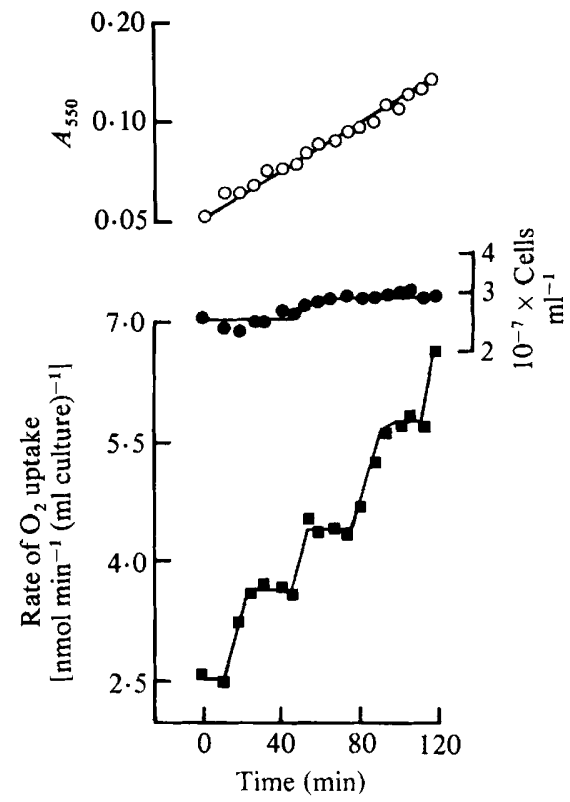

Fig. 4

Fig. 3. Effect of nalidixic acid added at different times during synchronous growth of $A$. eutrophus. Cell numbers are shown for untreated cultures $(O)$ and for cultures to which nalidixic acid $\left(10 \mu \mathrm{g} \mathrm{ml}^{-1}\right)$ was added at times $0(\nabla), 20(\square)$ or $60 \mathrm{~min}(\square)$. The increase in $A_{550}$ of untreated cells is also shown $(O)$.

Fig. 4. Oxygen uptake of cells selected by continuous-flow centrifugation and grown in the presence of nalidixic acid $\left(10 \mu \mathrm{g} \mathrm{ml}^{-1}\right) . \bigcirc, A_{550} ; 0$, cell numbers; $\square$, oxygen uptake rates.

\section{DISCUSSION}

Nalidixic acid inhibits subunit A of DNA gyrase in $E$. coli. This enzyme catalyses the introduction of negative superhelical turns in closed circular double-stranded DNA in an ATPdependent reaction. Thus nalidixic acid is a potent inhibitor of chromosome replication in $E$. coli (Gellert et al., 1976; Sugino et al., 1977; Cozzarelli, 1980). Nalidixic acid also inhibits DNA synthesis in A. eutrophus which, in cells growing asynchronously, results in the gradual cessation of cell division. This suggests a coupling between chromosome replication and cell division in $A$. eutrophus similar to that observed in E. coli (Dix \& Helmstetter, 1973). Addition of the antibiotic at different stages of the cell cycle provides evidence for a period during which nalidixic acid has little or no effect on cell division. That is to say, the earlier the time of its addition in the cycle the greater the inhibition of the subsequent cell division. This result is similar to previous data obtained for E. coli (Dix \& Helmstetter, 1973; James et al., 1975). This suggests that chromosome replication is confined to the early stages of the cell cycle of $A$. eutrophus. From a number of experiments similar to that described in Fig. 3, in which nalidixic acid was added at different times during synchronous growth, we conclude that the $\mathrm{C}$ period occupies approximately 0.45 of a cycle. Assuming a cycle time of $75 \mathrm{~min}$ then this corresponds to a time of about $35 \mathrm{~min}$.

Respiration rates of nalidixic acid treated cells of $A$. eutrophus increased in stepwise fashion similar to the rises in oxygen uptake rates observed in synchronously-growing cells. These stepped increases occurred with a frequency of approximately 0.5 of a cycle in both antibiotic treated and control cells. We conclude from these results that the respiratory periodicities observed during the cell cycle of $A$. eutrophus are not a function of chromosome replication or cell division. Some other cellular parameter must be exerting a changing energy demand through the cell cycle. It is unlikely that this results from changes in amounts of respiratory proteins such as cytochromes, since in $E$. coli many of these have been shown to increase continuously 
throughout the cell cycle (Poole et al., 1980). A possible reason for the observed periodicities might be a change in rates of synthesis of membrane lipids. It has been suggested that membrane lipids could be involved in regulation of membrane-associated enzyme activity. Rhodopseudomonas, Escherichia and Bacillus species all show changes in the rate of lipid synthesis during the cell cycle (Carty \& Ingram, 1981). Thus, the fact that many respiratory proteins are membranebound, and are intimately associated with lipids, makes the modulation of their activity by changes in membrane lipid composition an attractive possibility.

This work was supported by an SRC award, GR/A58890. We acknowledge the Royal Society for a grant to purchase the Coulter counter. We also thank Miss P. Pearce for technical assistance.

\section{REFERENCES}

Burton, K. (1956). A study of the conditions and mechanism of the diphenylamine reaction for the colorimetric estimation of deoxyribonucleic acid. Biochemical Journal 62, 315-323.

CARTY, C. E. \& InGram, L. O. (1981). Lipid synthesis during the Escherichia coli cell cycle. Journal of Bacteriology 145, 472-478.

Cozzarelli, N. R. (1980). DNA gyrase and the supercoiling of DNA. Science 207, 953-960.

Dix, D. E. \& Helmstetter, C. E. (1973). Coupling between chromosome completion and cell division in Escherichia coli. Journal of Bacteriology 115, 786795.

EDWARDS, C. \& JoNES, C. W. (1977). Respiratory properties of synchronous cultures of Alcaligenes eutrophus $\mathrm{H} 16$ prepared by a continuous-flow size selection method. Journal of General Microbiology 99 , 383-388.

EDWARDS, C. \& MCCANN, R. J. (1981). Differential effects of inhibitors on respiratory activity of synchronous cultures of Bacillus subtilis prepared by continuous-flow centrifugation. Journal of General Microbiology 125, 47-53.

Edwards, C., Spode, J. A. \& Jones, C. W. (1978). The properties of adenosine triphosphatase from exponential and synchronous cultures of Alcaligenes eutrophus H16. Biochemical Journal 172, 253-260.

Evans, J. B. (1975). Preparation of synchronous cultures of Escherichia coli by continuous-flow size selection. Journal of General Microbiology 91, 188190.

Gellert, M., Mizuuchi, K., O’Dea, M. H. \& Nash, H. A. (1976). DNA gyrase: an enzyme that introduces superhelical turns into DNA. Proceedings of the National Academy of Sciences of the United States of America 73, 3872-3876.

JAMES, R. (1978). Control of DNA synthesis and cell division in bacteria. In Companion to Microbiology, pp. 59-76. Edited by A. T. Bull \& P. M. Meadow. London: Longman.

James, R., Haga, J. Y. \& Pardee, A. B. (1975). Inhibition of an early event in the cell division cycle of Escherichia coli by FL1060, an amidinopenicillanic acid. Journal of Bacteriology 122, 1283-1292.

POOLE, R. K. (1977). The influence of growth substrate and capacity for oxidative phosphorylation on synchronous cultures of Escherichia coli K12. Journal of General Microbiology 99, 369-377.

Poole, R. K., Scott, R. I., Salmon, I., Gibson, J. F. \& MISRI, R. (1980). Development of membrane-bound respiratory components and their function in the bacterial cell cycle. Society for General Microbiology Quarterly 8, 22.

ScotT, R. I., Gibson, J. F. \& Poole, R. K. (1980). Adenosine triphosphatase activity and its sensitivity to ruthenium red oscillate during the cell cycle of Escherichia coli K12. Journal of General Microbiology 120, 183-198.

Sugino, A., Peebles, C. L., Kdruzer, K. N. \& Cozzarelli, N. R. (1977). Mechanism of action of nalidixic acid: purification of Escherichia coli nalA gene product and its relationship to DNA gyrase and a novel nicking-closing enzyme. Proceedings of the National Academy of Sciences of the United States of America 74, 4767-4771. 